\title{
The Contradictory Views on Ancient Literary Works as a Foundation of World Historical Development
}

\author{
Solehah Yaacob*, Ismail Haron \\ Kulliyyah of Islamic Revealed Knowledge \& Human Sciences, International Islamic University \\ Malaysia \\ solehah71@gmail.com
}

Keywords: Authenticity of the Document, Inscription, Fabricated and Forgeries, Propaganda, History

\begin{abstract}
Contradictory views on ancient literary works provide a panorama of historical development. However, the validity of the texts was considered as issue of prime importance. The critics on its literary authenticity would reveal whether it was real or just a fabrication. The Epic Gilgamesh was ascertained by Said Ghanimi to be unauthentic. The contentions by S. N. Kramer and Taha Baqir were with regard to the differences of language usage in the Epic Gilgamesh either Sumerian or Akkadian as well. The acknowledgement of the West on Iliad and Odyssey by Homer as the first document written in world history was unfounded although this was highlighted by B. Lansberger in $7^{\text {th }}$ conference in Paris on 1958. The Code Hamurabbi is a well preserved Babylonian Code of laws, unfortunately, it was considered as a fabrication of Old Testament which came 800 years later, especially on the narration of Big Flood Story as mentioned in the Book of Genesis. It is regrettable that the paucity of materials on the ancient history of the ancient people available from the Muslim sources poses as a constraint on this study. The research is compelled to refer almost entirely to Western and Jews sources. Thus, the approach used in this study is based primarily on historical and linguistic analysis of ancient literary works.
\end{abstract}

\section{Introduction}

The writings on tablets of ancient relics recovered at Mesopotamia have been regarded by archeologists and historians to be of great historical and cultural significance. It is regarded as a major watershed or landmark in the history of human civilization and culture. If we compare in terms of the oldness of literary works produced by humans these writings were regarded as the oldest of any human intellectual feats known to have been produced anywhere in the world. Studies verified that a great deal of written materials were in the language of Sumerian and Akkadian. These materials came to be known at a very much later date from the time it was written. It was gauged to be in existence at the beginning the era of second thousand BC. However, most of the works recovered could be dated to the era of third thousand BC. It could probably this was the period that literary creations became more preponderant. A comparison by viewing ancient Egyptian's relics would not do justice to Egyptian's ancient civilization as findings from Egyptian sources were scarce and not many artifacts were available to researchers. Nevertheless, it is known that the epoch known as the era of Pyramids saw a flourishing of Egyptian civilization which was said to produce massive amount of literary works. As evidenced by archeological findings at Ugarit the city of Canaanite it had been gauged that an advanced Egyptian's civilization was in existence in the later part of 1400BC. This underscored the point that Egyptian literature in written form appeared 500 years later than the writings of Mesopotamia discovery.

To examine briefly in terms of which civilization had existed earlier than the others a quick review would provide some rough indicators. It is known that Hebrew was not the original language of the Torah $\left[17\right.$, p. 272] ${ }^{1}$ came very much later than the language of ancient Iraq. The written Torah is said to be produced in the centuries between sixth $6^{\text {th }}$ or fifth $5^{\text {th }}$ century BC. The oldest examples

\footnotetext{
1 'A process of scriptural evolution: Canaanite, Aramaic (Assyrian) and finally square, which later on was renamed Hebrew".
} 
from Greeks literature were the Iliad and Odyssey. The oldest literature of ancient India is represented by Rig Veda. It is also known that Avesta and Alabestac were the oldest ancient Iranian literary works. The question is which of the ancient written literature had been written before the first half of the first thousand BC? It is probable that Iraq ancient literature was written at least 1000 years earlier than the date of its discovery and when it was brought to light it had lost to a large extent its original form at the time of writing [23, pp. 21-30]. Which is the oldest literary work of the ancient world is still enshrouded in mystery. The recorded of Epic Gilgamesh was gauged to be in existence around 4000 BC. However, there were several remarks on this epic such mentioned by Said al-Ghanimi it was fabricated especially on theology aspect [22, p. 320]. A question is in order to examine the Epic Gilgamesh within the context of development in ancient times. Is there any link or relatedness of Epic Gilgamesh with Arabic literature? If there is what is the extent of the linkage? If there is no affinity whatsoever then why is that so? Thanks to Western scholars for bringing to light vast amount of information through their serious efforts diligently uncovering engraved relics of Mesopotamia. Among these scholars are historians and archeologists of various nationalities: British, Italian, Austria, and Americans. These scholars are mainly the orientalists who focused their studies to understand ancient development in the east. In persons some of the identified orientalists are George Smith, a British national. He studied thousands of recovered ancient relics kept in museums in Britain. Most of these relics belonged to the ancient Nineveh [24, p. 182]. According to him the Epic Gilgamesh should be regarded or recognized as the best representatives or examples of ancient Iraq civilization [33, pp. 85-86]. The information from Epic Gilgamesh complement the epochal narrative of the great hurricane as recorded in the Torah [24, p. 182]. This is of particular interest to a big number of historians who believe that these two sources of information reported the same event, i.e, the Big Flood or the epochal hurricane. This means that the Epic Gilgamesh can be used to confirm ancient epics and narratives taken as a matter of faith throughout human history. The particular interest of historians on the Epic Gilgamesh is because it would serve as the watershed for historians to interpret the ancient times from a single most significant recorded catastrophic event.

\section{The Glory of Ancient Literature}

Around 3500 thousand stanzas of the Epic Gilgamesh were translated into English. It was spread around in England by R. Campbell Thompson in 1930 AD [24, p. 183]. That was the latest translation of the narratives of the Epic Gilgamesh until 1950 AD [34, pp.64-68]. With the publication of article by Taha Baqir in the "Sumer" journal, the information on Epic Gilgamesh became more widespread. Soon historians referred to the writings of Epic Gilgamesh as the Odyssey of ancient Iraq. The texts in the original was in the Akkadian language written in Mismariah form [5, p. 307] which was translated into Arabic in 1953 BC. According to Taha Baqir the Arabic translation was the only translation among many other well-known translations which came close to the original textual language of Akkadian. It is seen that there is a close and strong connection and relationship of the two languages, Arabic and Akkadian [34, pp. 64-68]. It is regrettable that the Epic Gilgamesh cannot be taken as a representation of the most distinguished ancient literary works from the perception of some scholars. They hold the view that in order to attain a more accurate view of its position and significance a comparison with other ancient civilizations over a wider spectrum is imperative. This view is articulated by B. Landsberger at a conference in Paris held in 1958 when he said, "I have a feeling that Epic Gilgamesh brings forth a kind of literary heritage of a particular heroic brand which is found in the history of other civilizations thought it was more expansive and complete. It was somewhat exalted indirectly acknowledging that the heroic relics of other civilization as being inferior. It does not compare or match with the literary relics of ancient civilizations before the Greeks." [34, p. 41].

This shows that the Western do not recognize the Epic Gilgamesh as a source of human creativity that could have affected other ancient civilizations not even the Iliad and Odyssey [5, pp.273-277]. According to Kramer the significance of Epic Gilgamesh centered upon the incident of the hurricane of the Torah. It provided the linkage by expanding and complementing the narratives of the Torah. Thus the narration of Epic Gilgamesh has effects upon the intellect and rationale of the 
nationals of many civilization owing to the striking semblance with the narration of the Torah. To Kramer the event and the story of the Epic Gilgamesh was quoted to be matching with the story of Mesopotamia Valley. According to Kramer dependence upon the event of the epochal hurricane taking it as the original historical incident and a historical reality could result in distorting the distant past [34, p.15]. He went further to say that as a result of magnification and exaggeration the impact of Epic Gilgamesh had far reaching influence on the mind of later generations everywhere and from word of mouth the narrative spread and got distorted from all aspect of the historical reality. So finally the narratives of the Epic Gilgamesh became identical to the narratives of the Torah on the great hurricane [34, p.13]. Most ancient literary production was oral not written. Even the written works were usually not preserved for the following generation because the writings were in ancient language not decipherable by them. So a consensus has been made among scholars who studied ancient literary works to claim that they have evidence that indicate that Iliad and Odyssey, the Greek literary works was the world's earliest production [7, pp.187-189]. A literary figure in Lebanon by the name of Sulaiman Al Bustani in the introduction to his Arabic translation of the Iliad, stress the point that the ancient Greeks were no scribers. He was of the opinion that Iliad poetries were oral stories similar to the oral traditions of the Arabs during the period of JÉhiliyyah. Before Islam stories and poetries were mere articulations which the masses memorized. Al Bustani surmised that the Iliad was not in written form before the adoption of the letters for writing from the Phoenicians. It was only in the $6^{\text {th }}$ century that it was rendered in writing using the Greek alphabets. As a consequence, Greek alphabets later spread throughout Europe and with adaptation and tinkering the Europeans soon had their own alphabets ready to embark on writing [14, p. 61]. However, al Bustani believes that Arab peninsular had played a major role with regard to its contribution to ancient literature as evidenced by relics of antiquity in the Arab peninsular. This will not be elaborated here as this study is not exploratory in nature. This study focuses in the main to establish the point that Greek sources were not the original source of Arabic literature as Arabic language and literature had gone through a process of independent evolution depending upon autonomous development from within its own civilization since the earliest of times.

\section{Innovators in Writing and Literature as Revealed from Ancient Artifacts}

According to Jurji Zaydan literature is the product of the intellect in expressing thoughts and feelings of a nation with varied roles in the life of the people contributing in the enrichment of knowledge, philosophy and culture as reflected in the history of the nations over time [13, p. 13]. In other words, literature as seen through its development in history demonstrates aspects of life of a nation with regard to their intellectual, philosophical and cultural and other life pursuits. In this sense, literature is not just confined to poetry or art but a totality of their life and history covering politics, economy and societal institutional structures. The question is: Who were the first to write poetry or who first invented writing or had the ability and inclination for compilation of written works? Writing has been established as the creation of the orient preceding the West by hundreds of years. Logically, the orient were the originators of literature as there cannot be literature without writing ability. Then, which nation was the earliest innovator to put knowledge in writing? The answer is straight forward. The enormous relics of ancient writings left behind by the orient were sufficient proofs of this. The evidence was relics discovered in places such as Egypt and Syria and the land between two rivers, Yemen and Hejaz and also Asia Minor, Persia, and India. The known written relics recorded and preserved are from the artifacts of the Pharaohs, Amorites, Phoenicians, Akkadians, Assyrians, Babylonians, Maronites, Samaritants and others.

Jurji Zaydan, for example, had established that the Greeks had historically gone through seven periods of development or epochs [13, pp. 21-22]. These are the epochs of Mythos, the Romanticist (Heroic) (900-700 BC) Early Civilized (700-500 BC) and The Golden age (500-323 BC), epoch of Alexandria (323-146) the epoch of Romans (146-550 ad) and the epoch of Byzantium (550-1453 $\mathrm{AD})$, finally the down of Greek civilization (1453 AD- until the establishment of Ottoman Empire). The Mythic age was painted as an age of advancement and excitement in Greek history but in actual fact the excitement was centered upon mythic tales of their gods and stories surrounding their 
superstitious beliefs. What is behind this picture of advancement? Does it mean to say that the emergence of the Greeks as a highly civilized nation preceded all other nations? If we look at the civilization at Mesopotamia valley, it is clear that at least there was a civilization surpassing the Greeks at a time when the Greeks were still in the dark age of Myths. How about the situations in other parts of the world? Adam Falkenstein in his article "The Prehistoric Age and the age of History in Western Asia [12, pp. 21-64] throw some light on this issue. Human advancement in Western Asia can be gauged from the successive volumes of written geographical and historical accounts. In the same light is the view from the article by Otto Adzard "The Age of Early Dynasties [12, pp. 65-98, 130-172, 173-250]. He mentioned that advanced human societies of the Sumerian and Semitic people during the early Dynasties had already existed preceding the Greeks. He also related the existence of mixed societies of the Sumerians, Akkadians, Amorites and the tribal Bedouins of Babylon society during the era of ancient Babylon. The advancement of the ancient Babylon was evidenced by the existence of castles, places of worship, canon laws and established cultures.

A question is thrown in here: Is it not odd to accord recognition to the Mesopotamia Valley only when there existed alongside it other civilizations? The Semitic Empires and the Babylon Kingdom with civilized and cultured settlements had been flourishing to the south-east and north of the Mesopotamia Civilization. In his book "Civilization of Nile Valley," Taha Baqir talked about the history of Arab Civilization, Sumerians in Iraq, and others: Amorites, Canaanites, Phoenicians, Aramaic and Hebrews and the later epochs [33, pp. 210-320] with regard to Amorites in the country of Syria. At the time of the great migration the Semitic came to be with them and the group of western Semitic assimilated the language of Western Semitic. The Semitic were known by their languages such as the Akkadian and branches of Babylon, Assyria among settlers in Iraq and the language southern Arabs [30, pp. 9-10].

As for the Syrians they had settled in their land from time immemorial, the initial migration of the Semitic people at about $3000 \mathrm{BC}$ was during a prehistoric time and so not much was known by the historians of the situations then [33, pp. 210-320]. However, as for the Amorites they were the proto Arab (Semitic) race known by racial categories and their stories in later times as recorded in history. Reverting again to Canaanites it was believed that they migrated to Syria together with the Amorites during the first wave of the great migration and they became known in setting up centers of civilizations of significance before the Canaanites. The earliest report of on Amorites appeared in chronicles of kings of Mesopotamia civilization such as in the report of Sargon the famous king of Akkad and also the founder of the Akkad Dynasty which left some artifacts of grand city of the Akkad "Tel al-Hariri" which according to inscriptions by Sumerians was written as "Marta or Mari"2 (dated as being in existence at the end of $2350 \mathrm{BC}$ ). The Amorites people were bent upon dividing the northern part of Syria and they began to push into central Syria and into Lebanon and from there extended their occupation southward into Palestine [33, p.233]. The dynasties, on the other hand, were enthused fully to control Iraq and put it in the worst clutch upon them as happened to early Babylon. The dynasties were famous the six kingdoms of Hamurabbi and more significantly the establishment of their dominion in the country of 'Assyur' and the attainment of ownership over the "Syria" and also from western Semitic around 1750 BC. The historians also uncovered the city of "Tel Hariri" and uncovered relics of great significance during the age of dynasties and the grand castle of kings [33, p. 235].

It was known that the recorders of relics had counted more than $(20,000)$ tin slates with writings using Mismariah letters in the language of Akkad, with inscriptions showing strong inclination to the dialects of Western Semitic (Amorite). The artifacts were regarded to be of great significance regarded as authentic and therefore useful in the tracing of the owners of the inscriptions and as a benchmark for establishing the authenticity of the artifacts themselves and elsewhere. Among the findings were records of communiqué and trading transactions which was linked to the dynasty kings (1730-1700 BC) [33, p. 235]. This established the close relationship between Amorites and Cananites [33, p. 240] or Phoenician who were at the time more preponderant than the Great Semitic tribes. The

\footnotetext{
${ }^{2}$ The Akkadian words.
} 
Phoenicians was known to have migrated to the inhabited part of Syria in the first wave of migration. It was explained that the Amorites and the Cananites had a certain affinity in the languages they used. They had close relations as they shared a branch of the language of the two races. These languages could be traced to a branch of the language of the Western Semitic [33, p.240].

Historians do have different opinions on how Syria was nurtured to grow into a top class civilization. Some believe it was due to impact of foreign culture but this was seen by others began to be felt only upon the people of Syria at a later time. As for the Amorites they established their center of government in the beginning at the northern part of Syria and here they received much cultural influence from the civilization of the Mesopotamia Valley and at the same time they assimilated the cultural elements of the Sumerians and Hawarian. As for the Canaanites they emerged as a highly developed civilized culture in the coastlines which also began to influence culturally the Egyptian civilization [33, p. 240]. As for the Aramaic ${ }^{3}$ consisting of the union of clans and tribes which became known with the mention in the writings of the Assyrian Kingdoms attributing them in the works of architectural designs ${ }^{4}$ especially in the era of Akhnaton. Perhaps Amorites in Eupharates Valley became distinguished and known as the United Aramaic [18, p. 162]. It was also noted that there were conflicts between the Assyrians and the Aramaic in the years (911-745 BC). Later the Aramaic people journeyed to the kingdom of Syria which noted that the kingdom of Aram located at the Aram river had emerged as trading nations with trading transactions with settlers around the two rivers Euphrates and Tigris which also was extended into the cities of Syria in the last part of the $13^{\text {th }}$ century BC. Later it was known that the land by the two rivers were occupied by new settlers and they built new kingship which became known as " فدان أرم" فان"

It was a small kingship with their center at "Haran" being located at a propitious location along trading routes and as a result they prospered and with it the culture of Aramaic was taken to greater height. Later, came along the wandering Hebrew ${ }^{6}$ people moving in the direction of Haran. Later, they finally settled in Palestine. As the narratives went, it was known that one of the renown of this people, Isaac married a woman of Haran (named Rifqh) and he later sent his son Jacob to Haran who later married (Leah) and (Rachel) ${ }^{7}$ (Genesis 21: 29, 4: 24). By the $11^{\text {th }}$ century BC the Aramaic established the kingship which later constructed its capital in Damascus which was called the "Aram City" [14, p. 29]. The exposition thus far established that there were linkages between Hebrew and the Aramaic. It was not uncommon for the mixing of languages to happen. It was also known that the language of the forefathers of the Hebrew known as Aramaic before they settled in Palestine also contained words from local dialects of the Canaanites [18, p. 164]. The findings also provide evidence that there was a cross lingual and cultural influence between them. It was also known that a lingo termed as Kanutzon was used by travellers in the area which consisted a mix-mix of words and expressions that could have resulted from the mingling between Hebrew and Aramaic.

\section{The Questions on Ancient Greek Civilization}

As revealed by the ancient artifacts apart from the Greeks, nations in other parts of the world had also undergone cultural and literary development. Ancient kingships, cultural and administrative centers of other civilizations were known to have existed. Ancient kingships had emerged with established societal institutions, political and economic system. Indeed, all this was evidenced by relics in the forms of artifacts and remains of building structures. This certainly refuted the perception that Greek was the solitary ancient civilization alone in the entire expanse of the world. Even though relics of other ancient civilizations were also discovered they had no knowledge value from the

\footnotetext{
${ }^{3}$ From Aramean those who established the civilization in Euphrates Valley, then known as 'Chaldean` then who established the Kingdom of Babylon.

4 Their old city.

5 The word فدان means `farm`or `domain`.

${ }^{6}$ Known as Bani Israel. They were different from Jews. The term `Hebrew` used because in Arabic called `Ibrani` while translated into English its becomes `Hebrew`. Actually this issue is misunderstood concept of Arabic when translated into English especially.

${ }^{7}$ The daughters of Laban.
} 
perception of the orientalists. As for the Greeks it was known that they were influenced by the writings of the Phoenician [7, p. 9] which means that Greeks borrowed the art of writing from the East. As stated by prof. Barry Powell, "West Semitic writing came to include two Branches: Northwest Semitic (Phoenician, Canaanite, Hebrew, Aramaic, Samaritan) and Southwest Semitic (North Arabic, South Arabic, Ethiopic). Derivatives of the script are still today preferred by Semitic speakers.... Among extant Phoenician inscriptions, in a repertory of signs clearly antedating the Greek, signs appear with similar shapes to those of the earliest Greek inscriptions. By way of reprimand he said "This genius and benefactor of mankind, who invented the Greek alphabet by adaption from the preexisting Phoenician syllabary, I will call the adapter' ${ }^{1}$. A central purpose of this study is to discover the motives of this man, whom we know by his fruits alone... have been in a place where Phoenician and Greeks intermingled, no doubt where there was continuing involvement between the two peoples [7, pp. 12-13].

It cannot be disputed that writing was the invention of the East and the Greeks actually adopted the writing system of the Phoenician. How did this happen? The Greeks began to write through contact with the language called "West Semitic" that was brought to them via the Canaanites [8, p.9]. Certainly there are Westerners who refuted this merely out of disdain or too much respect to Greek languages and philosophy. With regards to the Arab a question is in order here. Did the Arab possess a well-developed and refined language before Islam? Is it not the languages such as Moab, Saba', Himyar, Safawi, Thamudic from Arabic? If the answer is in the affirmative then why there is a lot of difference between their Arabic and the language of the Qur' an which baffled and vilified the Arabs, putting them in a state of awe and wonder.

We turn next to Arabic literature: In this respect our attention cannot but be arrested by the preponderant of Arabic literature. Arabic is among the richest language in the world. Jurji Zaydan describes Arab literary ingenuity in the following words, "the whole and the richest literature in all other languages of the world" [13, p. 22]. According to his classification Arabic literature falls in two broad categories: literary works before Islam in the period of the proto JÉhiliyyah and in the period of later JÉhiliyyah; and the other category is the works after Islam which mean after the coming of the Prophet (saw). This was the period of language and cultural transformation which provided the trend of development in the ears of the Ummawi, the Abbasi, the Moguls the Ottoman periods to the present day [13, p. 23]. Reverting to the "dark age" termed as the `JÉhiliyyah`it could be seen that language and literary works among the Arabs was one of the richest and most advanced in comparison to other civilizations of the time. In the proto JÉhiliyyah there were three subsets in literature in the language of Semitic i.e: the language of Akkad, Babylon, Assyria, Canaanites, Phoenician and Arabiah alongside the Hasbhi language. The family of Arabic language could be sub-grouped further into two: the north and the south [13, p. 24]. The current views among historians and linguists centered upon a question: Is Arabic at its peak or highest level of growth that it is not subject to further improvement or improvement is still possible? There cannot be a direct answer of "yes or no" to this question. A whole host of issues need be viewed. Is Arabic the original language of the peninsular? Were there other dialects existing alongside it? Were there linguistic differences among these dialects? Were there differences between them and Arabic? And finally, it is also important to know how was Arabic related to the languages of the east, west and south? The word 'Semitic' according to Schlozer (1781Ad) referred to the groupings of languages which evolved to emerge as the languages of Aramaic, Phoenician, Hebrew, Arabic, Yemeni, Babylon, and Assyria [35, p. 6]. What could be understood from here? Some take it to mean that these languages could be traced to Noah (pbuh) [21, p. 124]. The misconception of some historians and linguists who believe that Arabic was original to the peninsular was mentioned by Erica Reiner in "The history of the beginning of written record in human history" stating how the flow happened [20, p. 61]. It started with the flow of major languages: Akkadian and Sumerian. 


\section{The Relationship between Religion, Language and Civilization}

From Muslim perspective as well as other religions,' the most important to ask was, what was the language spoken by Adam (pbuh)? From the words of Allah in the Qur'an 'And He taught Adam the names' (al-Baqarah: 31). Raphael Loewe a historian on ancient Babylon said the language of Aramaic was the language spoken by Adam [19, p.103]. We are in agreement with this conception because if Adam spoke the language of Aramaic then it is it possible that the order given to Adam directly from God was Arabic in command usage. In view of this is it acceptable as suggested by some historians that the first language of the human race was Arabic? Some orientalists claim that Adam spoke the Aramaic language which was the language of the descendants of Noah (pbuh). The renown names of his off springs were five: Amorite, Assyur, Ailam, Arfakhsad and Aram (Genesis: 10). An issue arising here is Why Adam did not speak the language of Shem who was the eldest son of Noah? A quote from the prophet (pbuh) stated that Shem was father of the Arabs, Yapith father of Rome and Ham father of African people [19, p. 103]. We opine that the verse And We said, "O Adam, $d w e l l$, you and your wife, in Paradise and eat therefrom in [ease and] abundance from wherever you will. But do not approach this tree, lest you be among the wrongdoers." (al Baqarah: 35) clearly demonstrated God spoke directly to Adam without intermediary and what would this mean? In support of this view Kramer mentioned that the culture of Sumerian was very advanced at that time [25, pp. 269-273]. According to Wafi, Semitic was said to be in existence in around 2400 BC. They migrated to the countries of the east between two rivers and settled in areas around the Tigris river which was located at the town of Ashur. A group of the Semitic migrated southwards and mingled with the local inhabitants and their language through the process of the journey was named Akkad or Babylon-Assyria. This was evidenced by emergence of conurbations in areas where they inhabited as exemplified by Tal Emrnah. It was assumed that in 1411 to $1358 \mathrm{BC}$ the Akkadian represented the eastern branch of the hose of Semitic language [35, p. 27]. Erica Reiner in 2013 agreed with Wafi who stated that a compilations of words of commendations written around $1000 \mathrm{BC}$ was found to contain many grammatical errors in the Semitic copy - those were the translations borrowed from Akkad. The translation was believed to have been done to obtain religious liturgy in the language of Sumerian for the purpose of recitation or prayers that was considered authentic and valid [20, pp. 9098]. Some historians gathered evidence to surmise that Akkad was the official language while it was written in Mismariyyah as seen from the plentiful discovery of pieces of Akkadian dishes which contained agreement on sales of land. The writings of Mismariyyah had been mentioned in Canaanite language. It was mentioned that written rules were subject to enforcement through official texts (words) of the authentic canons (law). This enforcement of the laws explained why Assyrian chiefs did not involve in dispute with Palestine. Some small portion of endorsed stones containing Assyrian letters issued during the reign of King Sargon as discovered also attested to the perception of the significance of the Semitic language [1, p. 3]. The use of the term 'the language of Semitic by Schlozer was based on the findings from the engraved relics. He believed that all the Semitic languages were in the peninsular. But it is a wonder why the Semitic language was not typified as the language of the peninsular? What is the purpose behind the term Semitic? It has been conjectured that the languages of Semitics have an affinity with Shem, the son Noah. All these languages flowed to a place "the peninsular" (Baghdad Observer, 27 October, No. 3259) $)^{8}$. And with later migration the languages spread to places in northern, southern and eastern parts causing the rise of civilizations with marked influence upon culture, language, society and politics and economy of the eastern region. Some studies perceived that the Sumerian civilization was the most advanced of the ancient nations in enclaves of their own. It is now known that other nations existed after the golden age of the AkkadBabylon, therefore it is not logical to claim that the Sumerian were by themselves in isolation from the rest of the surrounding nations! Arab historians categorize three sub-groups of Arab ancient civilizations: the BÉidah, NAribah and Mustaribah. The Baidah were mentioned in the narratives but

\footnotetext{
${ }^{8}$ Arabic Translation and Intercultural Dialogue Association http://www.atida.org/ . Professor Sami Said al-Ahmad has replaced the term Semitic with another term `the language of al-Jaziriyah`otherwise Professor Abdul Wahab Muhammad al-Jaburi has introduced the term to `the languages of al-Aribah`http://www.atida.org/forums/showthread.php?t=10419.
} 
they belonged to the extinct peoples of the NAad and thamËd. The descendants of the Aribah carried the Arab traits exemplified by the tribes of Qahtan and Jurhum in Yemen and the tribes of AmÉliqah [11, pp.294-380], [27, v.1: p.29]. The MustaÑribah Arabs are the descendants of Ishmael (pbuh). He was recognized as Arab not by blood but through actions and deeds. His father prophet Ibrahim (pbuh) and the Lady Hagar were not of Arab descents. However, Prophet Ismail was a naturalized Arab by acquiring standard Arabic language and other traits from the Jurhum tribe [27, v.1: p. 433]. The important message could be revealed is the important and prominent language at that time was Arabic Fushah (standard Arabic). This brought Ishmael (pbuh) to learnt from Jurhum `s tribe [29, pp. 105106].

The above classification further clarified that the Arabs had from antiquity settled in the land of peninsular Arabia. This is further evidenced by large amounts of relics found in Yemen comprising remains of places of worship, grand pillars, monuments and memorials, bracelets and armlets. In the north of Hejaz were discovered remnants of the Thamudic at the border with Syria. [27, v.1: pp. 5052]. It was known that in the days of the second period of Jahiliyya they had achieved a level of language regarded as par excellent over and above other known languages of the time with respect to styles, linguistic forms, meanings, structure and syntax. Their spoken words, their poetry and plays displayed the use of standard Arabic with eloquence and accent similar to the language of the Qur'an. It was not probable that Arabic became a developed language one or two centuries before Islam as claimed by some orientalists. This highly advanced level of language must have much deeper roots in early ancient times. The pertinent question at this point: What is the original source of standard Arabic that became a highly developed language one or two centuries before Islam? According to Jawad Ali, Arabic could be traced to Babylon Akkadian or other kingships of Jurhum ${ }^{9}$. By the $20^{\text {th }}$ century BC Babylon reigned over the whole of Iraq and their language was regarded as Arabic [14, pp. 16-17]. A.F.L Beeston was in agreement with this view as articulated in his article "the evolution of Arabic language". He propounded that Arabic language surpassed the languages of other nations in age [4, pp. 1-26]. Arabic was already used in the commands on what was considered legal and illegal in decrees based on the laws of the Hamurabbi. The laws were well defined using appropriate expressions befitting the solemnity of the messages it contained. The evidence of this was found in engraved relics in the kingship of Susa written in the letters of the Mismarri on big pillars of black stones said to be in existence in $1800 \mathrm{BC}$. The inscriptions on stones contained laws from an advanced culture. The Humurabbi was also said to have set up schools to nurture their young ones though it was said that the disciplining method employed was rather oppressive according to modern standard. It is marvelous indeed that they already set up schools in their ancient towns 4000 years ago. They were known to have used stone slates where lessons for the children were inscribed consisting of exercises in arithmetic, spelling, multiplication tables etc. Search in their settlements yielded artifacts in the forms of books, wills or agreements, mathematics problems, astronomic observatory, historical texts and religious scriptures. There evidences to show their women were treated favorably. What has been established was that the kingship of Hamurabbi was an Arab kingship which could be considered as the oldest civilization on earth governed by laws and with devotion to knowledge. Over centuries their language, beliefs and thinking had undergone changes and they had also endured changes in climate during the period. It was found in comparison that the proto JÉhiliyyah and the JÉhiliyyah of the second period also shared some aspects of the core language, religion, mannerism. They were governed by shared common values in their dealings with their fellow men. The prophet Job (pbuh) had been recognized as an Arab. (Genesis: 10). The Arabs were the first in the production of poetry. The poetries in Arabic were later translated into Hebrew. This demonstrated that Arab's venture into literature was earlier than those of Iliad and Odyssey even the Mahabharat of the Hindus [13, p. 26].

According to Jurji Zaydan the language of Hamurabbi or Akkadian provided a typical image of being Arab in the Jahiliyya age. This could be a basis to confirm that they belong to Semitic language [28, pp. 282-283]. In the north were found relics written in their letters while the relics of Thamudic, Lahiyanic and Safawic were the relics of Arab jahili in the northern region indicating they had dwelled

\footnotetext{
${ }^{9}$ The Code Hamurabbi older 800 years than the Old Testament.
} 
there since the earliest of time. Their language was very advanced with grammatical order and structure. This showed the ancient language of northern Arab settlers reached maturity long before the production of poetry by Imru al-Qais in Mudar Arabic. The other relics were the Nabatean which was found since the $3^{\text {rd }}$ century of $270 \mathrm{AD}$. These comprised relics of Um al-Jamal and also the relics Zenobia all located in the south eastern Alepo discovered in 511 Ad. Also the relics of Haran in 568 Ad [13, p. 26].

From the point of view of Jawad Ali these ancient people described above were Arabs both in appearance and in blood. They were born and bred in the country of the Arabs. They were not migrants from any other place anywhere else. They never had outside guests who lived with them. So they were pure Arabs and their language was untainted by any other language. Relating to the perception of Jawad Ali, it is wrong to say that the Qur'an is not in authentic Arabic. It is in pure Arabic elevated and consolidated by Islamic messages. The Arabic of the Qur'an becomes the standard language of the Arabs. Indeed, there is a claim that the ancient writings of the Arabs were written in Torah from the books of Hebrew written in ancient language of ancient Greeks or Latin. It is also wrong to say that the language of the Qur'an is a dialect of a tribe living in the country of the Arabs whose language became the written language of the Arabs [11, pp. 33-34]. The translation of Epic Gilgamesh (the earliest discovered engravements) into Arabic happened much later. It was known that the information contained in Mesopotamia Valley that came to be known was not fully refined or true. This was because not all orientalists were along the same path or intent in the interpreting ancient relics. It could not be denied that there were those who sincerely studied ancient relics to discover the true happenings of ancient times. Studies on discovered relics have clearly established that Arabic is the most advanced of the ancient languages. It is also seen that there were other advanced ancient writings identified from relics left behind by ancient civilizations shared similar features with Arabic ancient writings. Similarities in word order, grammatical structure and sound system seem to suggest that these languages were offshoots of Arabic or originally from the same ancestral stock. It can, therefore, be safely concluded that Arabic is the mother language of the peninsular Arabia. Also it is the language of the Semitic not as claimed by "Schlozer". It is regretted that some orientalists tended to ignore certain findings and elevated some others, for example they regarded the writings of the Semitic as the most advanced compared to Akkadian and Semitic which had an affinity with ancient Arabic writings. The contention here is that the writing of Mismariyyah was not the most advanced writing in the ancient world, as compared to other writings; their words are seen to be similar to Arabic which could be inferred as a result of Arabic influence.

Discovery of relics left by the civilizations of Mesopotamia is an example of the fruit of diligence, concern and interest of Western archeologists and orientalists. They have worked hard to search for the relics, collect, document data and interpret them. They deserve praise for their zealous and continuing efforts. They uphold that the findings in the Mesopotamia serve as a benchmark for comparison with other ancient civilizations. On the basis of their comparison they could make plausible claims that particular ancient civilizations and languages were superior to others. This became documented sources on human development over the ages for the world to ponder and wonder. Since the orientalists were in the field earlier than others and exerted efforts in studying ancient relics what they say become accepted as true. Intentionally or inadvertently they could paint the picture of ancient civilizations to give undue credit to some civilizations and deny some others. Their presumptions, therefore, become the yardstick in determining which civilizations are recognized as being the forerunner in culture and language. They determine who pioneered in the creation of writing and in the production of literary works in ancient times. They could do this with confidence that their assumptions or views are correct as their knowledge of the ancient past are more comprehensive because they possess the main or major sources of information on many nations of antiquity [15, pp. 7-11, 14]. But where are the Muslims in this regard? Are we not obliged to bother and take steps to know what happened in the days earlier than the days of the Prophet Muhammad (pbuh)? Of course, it is well known that the powers that be of the kingdom of Saudi Arabia has been very supportive towards researching and studying ancient orient in particular since the reign of the King Fahad ibn Abdul Aziz of the Saud dynasty [16, pp. 15-129]. Without doubt, Muslims had lately 
shown great interest to study nations of antiquity but their numbers of experts are much smaller in comparison to the others.

The exposition thus far seems to confirm that Arabic is a language of antiquity and was the most advanced in comparison to languages of other civilizations existing at that ancient time. Another interesting observation is that many ancient languages showed some semblances with Arabic in syntax, grammatical structure and sound of utterances. It can be established that they are of the same language family. In fact, in comparison there were other writings with words similar to Arabic which were more advanced and in much earlier time than the Mismariyyah. According to Beeston some findings in the form of writings of the early Furat (proto Euphrates) indicated that they lived to the south of the river Euphrates around five or four thousand years BC. This finding lends support to Jurji Zaydan opinion that peninsular Arabia belong to the Arabs and the Arabs were the ancient people who had inhabited and established their possession of the peninsular since ancient times.

\section{Conclusion}

It is important for Muslim scholars to take cognizant the fact that if they do not present a rebuttal on the positions of orientalists on some issues arising from their misperception with regard to ancient historical events then the whole world would believe them including the Muslims themselves. A laid back attitude among Muslim scholars would give the orientalists the monopoly in interpreting events in the east. It is the general perception of the world today that the Greeks were the pioneers in knowledge in the sciences and philosophy. The position accorded to the Greeks resulted from interpretations by Western historians and archeologists of Greeks achievement in the ancient time without comparing them to other civilizations more developed than the Greeks. Though, other developed civilizations existed as evidenced by their relics from recent discovery there was no attempt to give deserving recognition to them. It must be noted that orientalists have exerted much efforts in investigation and collection of ancient relics to come up with evidence and data to make plausible interpretations and spread their findings to the rest of the world, perhaps, with a certain purpose in mind that may not be too favorable to the Muslims' perception and interpretations of the ancient times. The Arabs and Muslims as a whole appeared to have fallen short in their research on ancient civilizations and even on the ancient Arabs. This provided opportunities for the orientalists to have a field day over the main sources of evidence to provide their interpretations of events and the state or conditions of ancient civilizations everywhere in the world. It is noted that Arabic is in a league of its own considered as the most advanced compared to other languages in ancient civilizations. Arabic is the mother tongue of the people of peninsular Arabia. It is the mother language of the Semitic language and other offshoots of the same family of languages regarded to have existed since antiquity. Some considered that the writing of Mismariyyah was among the most advanced in word arrangements or organization of writings because some languages of the Semitic for example Akkadian were found to be written in Mismariyyah letters. In order to put a slight on the achievements of ancient Arabs in writing some orientalists recognized that the writings of the ancient Furat (Euphrate) are superior in organization compared to the writings of the Sumerian. This point does not reduce the position of Sumerian as Furatees were also a clan of the Arabs. Jurji Zaydan is unbiased when he states that the Arabs were the most advanced nation in peninsular Arabia in ancient time. He also categorically states that the Arab peninsular belongs to the Arabs since time immemorial. Some orientalists including Zaydan though not an Arab dare to say what they believe to be true though contrary to the views of many others. This attitude among orientalists objectively seeking to know the truth is indeed praise worthy. When it concerns the affairs of Muslims who else would come up as the spoke persons for the Muslims if not the Muslim scholars? It is very encouraging now in the twenty-first century Muslim scholars have been vocal on issues related to Muslims and have provided answers to clarify misinterpretations from non-Muslim scholars in many fields of knowledge. Likewise, the views presented in this paper is also with the idea of continuing the trend of research in order to rebuttal misconceptions and incorrect interpretations with regard to ancient history touching upon language and literature related to or belonging to the Muslims. 


\section{References}

[1] Adolphe Lods, The Prophets and The Risen of Judaism, translated by S. H. Hooke in the History of civilization edited by C. K. Ogden, London: Routledge, 1996.

[2] A.F.L. Beeston, Takwim Fi an-Nuqush al-Arabiyah al-Janubiyah, Translated by Said Ghanimi, Abu Dhabi: al-Majma`at-Thaqafi, 2009.

[3] Adolphe Lods, The Prophets and The Risen of Judaism, Translated by S. H. Hooke in the History of civilization edited by C. K. Ogden, London: Routledge, 1996.

[4] A.F.L Beeston, Arabic Literature To The End of The Umayyad Period, New York: Cambridge University Press, 1983.

[5] Amir Sulayman, Al-Turath al-Lughawy in Encyclopedia of Iraq Civilization, Baghdad: Open Publication, 1985.

[6] As-Suyuti, Al Muzhir Fi Ulum al-Arabiyah Wa Anwa`uha. Beirut: Dar al-Kutub al-Ilmiyah, 1998.

[7] Barry B. Powell, Homer and the Origin of the Greek Alphabet, Cambridge: Cambridge University Press, 1991.

[8] D.S. Margoliout, The Relation Between Arabs and Israelites Prior to the Rise of Islam, London: British Academy, 1924.

[9] Georges Roux, Ancient Iraq, London: George Allen and Unwin LTD. 1965.

[10] Giulio Lepschy, Linguistics in the Ancient Near East in History Of Linguistics, Longman: London. 1965.

[11] Jawad Ali, Al-Mufassal Fi Tarikh al-Arab Qabla al-Islam. Volume 1. Baghdad: Jamiah alBaghdad, 1976.

[12] Jane Potter et al., As-Shirq al-Adna al-Hadharat al-Mubakirah, Translated by Amir Sulayman, Britain: Del Publisher, 1967.

[13] Jurji Zaydan, Tarikh al-Adab al-Lughah al-Arabiyah. Volume 1. Cairo: Dar al-Hilal, 2011.

[14] Khair Bik Magid, Al-Lughah al-Arabiyah Juzuruha, Intisharuha wa Ta thiruha. Fi as-Sharq wa al-Gharb. Damascus: Dar as-Sa`duddin, 1992.

[15] M. Matbaqani, Buhuth Fi al-Istishraqi al-Amerika al-Mu asir. Riyadh: Al-Mamlakah alArabiyah as-Saudiah Wizarah at-Talim al-`Alami, 2000.

[16] M. Matbaqani, Al-Mamlakah al-Arabiyah as-Saudiah Fi al-Ihtimam Bi Dirasat alIstishraqiyah. Riyadh: Al-Mamlakah al-Arabiyah as-Saudiah Wizarah at Talim, 2005.

[17] M.M. Al-Azami, The History of the Quranic Text, Second Edition, UK: UK Islamic Academy, 2011.

[18] P.K. Hitti, The History of Syria. Available: www.questia.com/.

[19] R. Loewe, Hebrew Linguistics. 'In History of Linguistics`, vol. 1, Edited by Guilio Lepschy, London: Longman, 1994.

[20] E. Reiner, Linguistics in the Ancient near East in History of Linguistics, Edited by Giulio Lepschy, London, England: Longman, 1990.

[21] G. Roux, Ancient Iraq. London, England: George Allen and Unwin LTD, 1965.

[22] Said al-Ghanimi, Yanabi`al-Lughah al-Ula, Abu Dhabi: Al-Imarat al-Arabiyyah al-Mutahidah, 2009. 
[23] Samual Noah Kramer, Sumerian Mythology, 1961. Available: https://keychests.com/item.php?v=ddpbjrdzaux

[24] Samual Noah Kramer, History Begins At Sumer, USA: Samuel Noah Kramer, 1959.

[25] Samual Noah Kramer, The Sumerians, Their history, Culture and Character, US: Univ. of Chicago Press, 1963.

[26] Selected Iraqis Researchers, Hadharat al-Iraq. Volume 1. Baghdad: Jamiah Baghdad, 1985.

[27] Al-Suyuti, Al-Muzhir Fi Ulum al-Lughah Wa Anwa`uha, Beirut: Dar Dar al-Kutub al-Ilmiah, 1998.

[28] S. Yaacob, Arabic Language as the Foundation of Semitic Languages, Arab World English Journal. 5(3) (2014) 278 -290.

[29] S. Yaacob, The Origin of the Arabs: A Critical Evaluation of the Sources, The Islamic Quarterly Journal. 58(2) (2014) 95-113.

[30] S. Yaacob, The Intricacy and Delicacy in the Historical Development of Arabic Language, Dewan Bahasa \& Pustaka (DBP) Malaysia, 2016.

[31] Sulayman Abdul Rahman az-Zabib, Madkhal Ila Qawaid an-Nuqush an-Nabatiyah, 2001. Available: www.kfnl.gov.sa/idarat/alnsher\%20el/Nabateaen/klaf.htm.

[32] Sulayman Abdul Rahman az-Zabib, Qawaid al-Lughah an-Nabatean, 2011.

[33] Taha Baqir, Muqaddimah Fi Tarikh al-Hadharat al-Qadimah - Hadharat Wadi al-Nayl, Baghdad: Open Publication, 1956.

[34] Taha Bakir, Milhamah Gilgamesh. Baghdad: Dar As-Shuun at-Thaqafiah al- Amah, 1986.

[35] Abdu al-Wahid Wafi, Fiqh al-Lughah, Cairo: Dar an-Nahdah, 1988. 